\title{
Soil physical and microbiological attributes cultivated with the common bean under two management systems ${ }^{1}$
}

\author{
Atributos físicos e microbiológicos do solo cultivado com feijoeiro em dois sistemas \\ de manejo
}

\author{
Lorena Adriana De Gennaro², Zigomar Menezes de Souza ${ }^{2 *}$, Mara de Andrade Marinho Weill², Gustavo Soares \\ de Souza $^{3}$ e Marlene Cristina Alves ${ }^{4}$
}

\begin{abstract}
Agricultural management systems can alter the physical and biological soil quality, interfering with crop development. The objective of this study was to evaluate the physical and microbiological attributes of a Red Latosol, and its relationship to the biometric parameters of the common bean (Phaseolus vulgaris), irrigated and grown under two management systems (conventional tillage and direct seeding), in Campinas in the state of São Paulo, Brazil. The experimental design was of randomised blocks, with a split-plot arrangement for the management system and soil depth, analysed during the 2006/7 and 2007/8 harvest seasons, with 4 replications. The soil physical and microbiological attributes were evaluated at depths of 0.00-0.05, 0.05-0.10, 0.10-0.20 and 0.20-0.40 m. The following were determined for the crop: density, number of pods per plant, number of beans per pod, thousand seed weight, total weight of the shoots and harvest index. Direct seeding resulted in a lower soil physical quality at a depth of 0.00-0.05 m compared to conventional tillage, while the opposite occurred at a depth of 0.05-0.10 m. The direct seeding showed higher soil biological quality, mainly indicated by the microbial biomass nitrogen, basal respiration and metabolic quotient. The biometric parameters in the bean were higher under the direct seeding compared to conventional tillage.
\end{abstract}

Key words: Soil structure. Soil organic matter. Soil microbial activity. Direct seeding. Phaseolus vulgaris.

\begin{abstract}
RESUMO - Os sistemas de manejo agrícola do solo podem alterar sua qualidade física e biológica, interferindo no desenvolvimento das culturas. O objetivo do trabalho foi avaliar os atributos físicos e microbiológicos de um Latossolo Vermelho e sua relação com parâmetros biométricos do feijoeiro (Phaseolus vulgaris) irrigado cultivado em dois sistemas de manejo (preparo convencional e semeadura direta), em Campinas-SP. O delineamento experimental foi em blocos casualizados com arranjo em parcelas subdivididas para sistema de manejo e profundidade do solo, analisados nas safras de 2006/07 e 2007/08, com 4 repetições. Os atributos físicos e microbiológicos do solo foram avaliados nas profundidades de $0,00-0,05 ; 0,05-0,10 ; 0,10-0,20$ e 0,20-0,40 m. Para a cultura foram determinados: estande, número de vagens por planta, número de grãos por vagem, massa de mil grãos, massa da parte aérea total e o índice de colheita. A semeadura direta resultou em menor qualidade física do solo na profundidade de 0,00-0,05 m em relação ao preparo convencional, ocorrendo o inverso na profundidade de $0,05-0,10 \mathrm{~m}$. O solo em que foi feita a semeadura direta apresentou melhor qualidade biológica, indicada, principalmente, pelo nitrogênio da biomassa microbiana, respiração basal e quociente metabólico. Os parâmetros biométricos do feijoeiro foram superiores no sistema semeadura direta em relação ao convencional.
\end{abstract}

Palavras-chave: Estrutura do solo. Matéria orgânica do solo. Atividade microbiana do solo. Semeadura direta. Phaseolus vulgaris.

\footnotetext{
*Autor para correspondência

Recebido para publicação em 07/03/2013; aprovado em 06/06/2014

Extraído do trabalho de Mestrado do primeiro autor no Programa de Pós-Graduação em Engenharia Agrícola da FEAGRI/UNICAMP, com financiamento de bolsa pela CAPES e do projeto pelo CNPq

${ }^{2}$ Faculdade de Engenharia Agrícola, Universidade Estadual de Campinas, Campinas-SP, Brasil, lorena.gennaro@feagri.unicamp.br, zigomarms@ feagri.unicamp.br, mweill@feagri.unicamp.br

${ }^{3}$ Fazenda Experimental Bananal do Norte, Instituto Capixaba de Pesquisa, Assistência Técnica e Extensão Rural, Cachoeiro de Itapemirim-ES, Brasil, gustavo.souza@incaper.es.gov.br

${ }^{4}$ Faculdade de Engenharia, Universidade Estadual Paulista “Júlio de Mesquita Junior”, Ilha Solteira-SP, Brasil, calves@agr.feis.unesp.br
} 


\section{INTRODUCTION}

In conventional tillage, intensive turning of the soil in unsuitable conditions of moisture and cover vegetation modify its structure, affecting the relationship between the solid, liquid and gas phases (BERTOL et al., 2004; WENDLING et al., 2005). In a no-tillage system, there is no preparation of the soil, as sowing is carried out on top of the remains of previous crops. This management system is effective in protecting the surface of the soil, but as the soil is not turned, compacted layers may form over time due to pressure on the soil surface by machinery and agricultural implements (ASSIS; BERTOL et al., 2004; LANÇAS, 2005;).

While the soil under no-tillage has greater density and lower macroporosity in the surface layer (LIBARDI, 1998; SILVA; SECCO 2005; TORMENA et al., 1998), an increase in the levels of organic matter can reduce the density of the soil over time and increase the volume of cavities (CARNEIRO et al., 2009). Soil quality therefore becomes a function of when the no-tillage system was adopted, tending towards improvement in the physical, chemical and biological properties of the soil (ASSIS; LANÇAS 2005; CARNEIRO et al., 2009). In this way a no-tillage system contributes to the sustainability of agricultural systems, keeping cover crops or crop residues on top of the soil, minimising the effects of erosion and maintaining the level of organic matter (BERTOL et al., 2004).

Surveys have shown changes in soil microbial activity brought about by different agricultural management systems (AMARAL et al., 2011; CUNHA et al., 2011; MOURA; LACERDA; RAMOS, 2013). Silva et al. (2007), when evaluating the biological attributes of the soil as a function of vegetation cover and system of management, observed that the soil under direct seeding demonstrated a greater intermediate carbon content for the microbial biomass in relation to native forest (greater content) and a conventional tillage system (smaller content). Cunha et al. (2011) observed improvements in the biological activity of soil cultivated with beans under direct seeding in relation to conventional tillage.

In a conventional system, the increased mechanical tillage results in a greater loss of organic matter and consequently a reduction in the microbial biomass. Conservation agriculture, due to including the practices of green manure, crop rotation and direct seeding, is able to increase, or at least maintain, the levels of organic matter in the surface layers of the soil, to reduce nutrient losses through immobilisation by microorganisms and to release nutrients gradually (CARNEIRO et al., 2009); this may result in greater development of the crop in the medium term (SANTOS et al., 2004).
In this context, the present work is based on the proposition that soil under a direct seeding displays better physical and biological qualities in relation to soil under conventional tillage, favouring the development of bean plants under sprinkler irrigation. The aim of the study was to evaluate the soil physical attributes and soil biological activity, and their relation to the biometric parameters of irrigated bean plants under management systems employing conventional tillage and direct seeding.

\section{MATERIAL E METHODS}

The experiment was carried out in the town of Campinas, in the state of São Paulo, Brazil, in an area of typic dystrophic Red Latosol of a clayey texture (EMPRESA BRASILEIRA DE PESQUISA AGROPECUÁRIA, 2013), at $22^{\circ} 48^{\prime} 57^{\prime \prime} \mathrm{S}$ and $47^{\circ} 03^{\prime} 33^{\prime \prime} \mathrm{W}$, and an average altitude of $640 \mathrm{~m}$. Using the Köppen classification, the regional climate corresponds to a transition between types Cfa and Cwa, indicative of a highland tropical climate with dry winters and wet summers (KÖPPEN, 1948). The average annual rainfall is $1,382 \mathrm{~mm}$, with the rainy season between October and March (1,048 mm).

The experimental design was of randomised blocks in an arrangement of split plots with four replications; two agricultural years being analysed separately. The management system made up the main plots with soil depth for the subplots. The management systems evaluated were: (i) conventional tillage with one pass of a disk harrow for turning the soil to a depth of $0.10 \mathrm{~m}$, and (ii) direct seeding onto oat crop residue. The experiment was set up during the 2003/04 season, with evaluations being carried out during the harvests of 2006/07 and 2007/08. Experimental plots with an area of $600 \mathrm{~m}^{2}(30 \times 20 \mathrm{~m})$ were used.

The crop installed was the IAC-Carioca variety of bean. A crop spacing of $0.45 \mathrm{~m}$ between rows was used, with 12 seeds per linear meter and a population of 230,000 plants per hectare. Seedling emergence took place eight days after sowing. Basic fertilization, taking analysis of the soil into account, was carried out in the sowing furrows by applying $200 \mathrm{~kg} \mathrm{ha}^{-1}$ of formula 4-14-8. A topdressing of nitrogen fertilizer was applied 25 days after emergence (DAE), when the plants were at stage V4 (issue of the third trifoliate leaf), applying $20 \mathrm{~kg} \mathrm{~N} \mathrm{ha}^{-1}$ as urea. For the winter crops, conventional spray irrigation was used, keeping the water content of the soil near field capacity by the application of a total depth of $285.8 \mathrm{~mm}$ of water.

After each harvest, both disturbed and undisturbed soil samples were removed in order to characterise the physical and microbiological attributes at depths of $0.00-0.05 \mathrm{~m}, 0.05-0.10 \mathrm{~m}, 0.10-0.20 \mathrm{~m}$ 
and $0.20-0.40 \mathrm{~m}$, for the two management systems. Soil sampling was carried out for the two growing seasons in 16 trenches ( 2 replications per plot) which were randomly distributed within each plot, totalling 1,024 observations (16 trenches $\mathrm{x} 4$ plots $\mathrm{x} 8$ depths $\mathrm{x} 2$ harvests).

Undisturbed soil samples were collected in volumetric rings, $0.03 \mathrm{~m}$ in height and $0.05 \mathrm{~m}$ in diameter, to determine the soil density and soil porosity. Microporosity was determined with a tension table and corresponded to the volume of moisture retained in the sample after being saturated and subjected to a pressure of $6.0 \mathrm{kPa}$. The total porosity and the soil density were obtained as per EMBRAPA (2011), and the macroporosity by the difference between the total porosity and the microporosity. The soil water content was taken at the same time as the soil penetration resistance was determined with the gravimetric method (EMBRAPA, 2011). In order to determine the soil penetration resistance, an impact penetrometer with a cone angle of $30^{\circ}$ was used. The soil penetration resistance was determined according to Stolf, Reichardt and Vaz (2005).

The total organic carbon and nitrogen of the soil were quantified as per EMBRAPA (2011). To determine the microbial biomass carbon, the fumigation-extraction method was employed using an aqueous solution of $0.5 \mathrm{M} \mathrm{K}_{2} \mathrm{SO}_{4}$ (VANCE; BROOKES; JENKINSON, 1987). The fumigation-extraction method was also used to quantify the biomass nitrogen, with the extract used in this evaluation being the same as used in the quantification of the biomass carbon (JENKINSON, 1988). The Pramer and Schmidt method (1964) was used to quantify the basal respiration, the amount of $\mathrm{C}-\mathrm{CO}_{2}$ released by the soil. The metabolic quotient was obtained by the relationship between the $\mathrm{C}-\mathrm{CO}_{2}$ released through basal respiration and the microbial biomass carbon. The microbial quotient was obtained by the ratio of microbial biomass carbon to the total organic carbon.

The initial plant density of the bean crop was determined right after plant emergence. Before the bean harvest, five plants representing each plot were collected in order to determine the number of pods per plant, number of grains per pod and the thousand-grain weight. The shoot dry weight was estimated by harvesting samples, $5.0 \mathrm{~m}$ in length, from the two centre rows of each plot. The harvest index (HI) was determined by the ratio between the weight of the grains and the shoot dry weight.

The results for the soil attributes and the biometric parameters of the bean plant were subjected to variance analysis and the means compared by Tukey test $(\mathrm{p}<0.05)$ using the SAS ${ }^{\circledR}$ software.

\section{RESULTS AND DISCUSSION}

Average values for organic matter content under the management systems, for the depths and seasons studied, are shown in Table 1. There was no significant effect from the management systems on this variable, for the depths or seasons under study. The organic matter content did not differ between management systems. This occurred because the period of installation of the direct seeding (third and fourth years after initial planting) was insufficient to point out significant differences for this attribute between the management systems. These results agreed with those of Assis and Lanças (2005), who found similar levels of organic matter in a Red Nitosol under a direct seeding 1, 4 and 5 years after installation, compared to a conventional tillage system. Cunha et al. (2011) also found no difference in total organic carbon for direct seeding and conventional tillage systems in a bean crop at depths of $0.00-0.10$ and $0.10-0.20 \mathrm{~m}$.

In the 2006/07 crop season, the levels of organic matter at $0.00-0.05$ and $0.05-0.10 \mathrm{~m}$ did not differ, but both were higher than at $0.10-0.20$ and $0.20-0.40 \mathrm{~m}$ (Table 1$)$. In 2007/08, the conventional tillage system displayed a similar trend to the previous season; however under direct seeding the content at $0.00-0.05 \mathrm{~m}$ was higher than at the other depths. The results show evidence of changes promoted by the direct seeding, since the system is not consolidated, having a larger input of organic residue to the surface, which helped to increase the organic matter in the soil, whereas under conventional tillage, the action of the harrow on the 0.00-0.10 m layer tends to homogenize the turned soil (BERTOL et al., 2004;. WENDLING et al., 2005). Assis and Lanças (2005) observed that after 12 years under direct seeding, the levels of organic matter in the soil were greater than under conventional tillage, approaching that of soil under native forest, and in agreement with this work.

There were significant differences seen between the management systems for soil density, total porosity and macroporosity at depths of $0.00-0.05 \mathrm{~m}$ and $0.05-0.10 \mathrm{~m}$, with no differences at the greater depths for the two seasons under analysis. Soil density under the direct seeding at a depth of 0.00-0.05 $\mathrm{m}$ was higher than under the conventional system, with total porosity and macroporosity being consequently lower. This was due to the absence of preparation of the soil and the past use of agricultural machinery. Similar results were found by Bertol et al. (2004), Secco et al. (2005), Tormena et al. (2008) and Tormena, Silva and Libardi (1998).

The higher values of organic matter at a depth of 0.00-0.05 $\mathrm{m}$ were not sufficient to reduce the value of soil density and increase porosity, corroborating results obtained by Bertol et al. (2004). However, at a depth of 0.05-0.10 m, soil density was higher under 
conventional tillage, with lower values for total porosity and macroporosity bought about by the working depth of the harrow which compacted the soil below the layer of turned soil.

At the depths under study, the penetration resistance of the soil displayed high values $(>2.0 \mathrm{MPa})$, agreeing with Tormena, Silva and Libardi (1998), with a similar trend between the management systems as that seen for bulk density (Figure 1). These results are in agreement with the data obtained by Kaiser et al. (2009). As the water content of the soil did not differ for management system or depth, the differences in penetration resistance occurred due to the effect of agricultural management, which in the case of the direct seeding resulted in compaction of the surface layer due to the soil not being turned and the accumulation of the effects caused by the tyres of the agricultural machinery over consecutive years.

Conventional-tillage management showed higher soil penetration resistance at a depth of $0.05-0.10 \mathrm{~m}$ for the two crop seasons, agreeing with Carneiro et al. (2009).
These results indicated the effect of conventional tillage resulting in compaction of the soil below the surface layer. This compression concentrates plant root development close to the surface, limiting the volume of soil exploited (KAISER et al., 2009). The soil penetration resistance also increased from the 2006/07 to the 2007/08 season under conventional tillage at a depth of $0.05-0.10 \mathrm{~m}$, caused by contact of the soil and implements, something which did not occur under direct seeding. This probably shows degradation of the physical quality of the subsurface soil, agreeing with Kaiser et al. (2009).

For the two seasons under study, the highest values for soil density and soil penetration resistance in the surface layer, as well as the lowest values for total porosity and macroporosity under the direct seeding are due to the soil not being turned which when associated with machinery, promotes soil compaction. The soil penetration resistance decreases with depth, indicating compaction of the surface layer for the two seasons under study, which is caused by the machinery together with not turning the soil. It can be seen that

Table 1 - Soil physical attributes and soil organic matter content under direct seeding (DS) and conventional tillage (CT) at four depths and in two harvest seasons

\begin{tabular}{|c|c|c|c|c|c|c|c|c|}
\hline \multirow{4}{*}{ Management system* } & \multicolumn{8}{|c|}{ Depth (m) } \\
\hline & $000-0.05$ & $005-0.10$ & $010-0.20$ & $020-0.40$ & $000-0.05$ & $005-0.10$ & $010-0.20$ & $020-0.40$ \\
\hline & \multicolumn{8}{|c|}{ 2006/07 Season } \\
\hline & \multicolumn{4}{|c|}{ Organic Matter $\left(\mathrm{g} \mathrm{kg}^{-1}\right)$} & \multicolumn{4}{|c|}{ Soil Density $\left(\mathrm{kg} \mathrm{dm}^{-3}\right)$} \\
\hline DS & $4.4 \mathrm{Aa}$ & $4.2 \mathrm{Aa}$ & $3.7 \mathrm{Ab}$ & $3.1 \mathrm{Ac}$ & $1.34 \mathrm{Aa}$ & $1.26 \mathrm{Bb}$ & $1.27 \mathrm{Ab}$ & $1.28 \mathrm{Ab}$ \\
\hline $\mathrm{CT}$ & $4.3 \mathrm{Aa}$ & 4.1 Aa & $3.7 \mathrm{Ab}$ & $2.8 \mathrm{Ac}$ & $1.27 \mathrm{Ba}$ & $1.31 \mathrm{Aa}$ & $1.28 \mathrm{Aa}$ & $1.26 \mathrm{Aa}$ \\
\hline \multirow[t]{2}{*}{$\mathrm{CV}(\%)$} & \multicolumn{4}{|c|}{8.1} & \multicolumn{4}{|c|}{4.4} \\
\hline & \multicolumn{4}{|c|}{ Total Porosity $\left(\mathrm{m}^{3} \mathrm{~m}^{-3}\right)$} & \multicolumn{4}{|c|}{ Macroporosity $\left(\mathrm{m}^{3} \mathrm{~m}^{-3}\right)$} \\
\hline DS & $0.51 \mathrm{Ba}$ & $0.54 \mathrm{Aa}$ & $0.52 \mathrm{Aa}$ & $0.48 \mathrm{Aa}$ & $0.13 \mathrm{Bb}$ & $0.16 \mathrm{Aa}$ & $0.11 \mathrm{Ab}$ & $0.10 \mathrm{Ab}$ \\
\hline $\mathrm{CT}$ & $0.57 \mathrm{Aa}$ & $0.45 \mathrm{Bb}$ & $0.49 \mathrm{Ab}$ & $0.49 \mathrm{Ab}$ & $0.18 \mathrm{Aa}$ & $0.07 \mathrm{Bb}$ & $0.09 \mathrm{Ab}$ & $0.08 \mathrm{Ab}$ \\
\hline \multirow[t]{3}{*}{$\mathrm{CV}(\%)$} & \multicolumn{4}{|c|}{6.3} & \multicolumn{4}{|c|}{18.1} \\
\hline & \multicolumn{8}{|c|}{ 2007/08 Season } \\
\hline & \multicolumn{4}{|c|}{ Organic Matter $\left(\mathrm{g} \mathrm{kg}^{-1}\right)$} & \multicolumn{4}{|c|}{ Soil Density $\left(\mathrm{kg} \mathrm{dm}^{-3}\right)$} \\
\hline DS & $4.5 \mathrm{Aa}$ & $3.9 \mathrm{Ab}$ & $3.4 \mathrm{Ac}$ & $3.1 \mathrm{Ac}$ & $1.32 \mathrm{Aa}$ & $1.25 \mathrm{Bb}$ & $1.28 \mathrm{Ab}$ & $1.29 \mathrm{Ab}$ \\
\hline $\mathrm{CT}$ & $4.1 \mathrm{Aa}$ & $3.9 \mathrm{Aa}$ & $3.6 \mathrm{Ab}$ & $3.1 \mathrm{Ac}$ & $1.28 \mathrm{Ba}$ & $1.34 \mathrm{Aa}$ & $1.30 \mathrm{Aa}$ & $1.28 \mathrm{Aa}$ \\
\hline \multirow[t]{2}{*}{$\mathrm{CV}(\%)$} & \multicolumn{4}{|c|}{8.0} & \multicolumn{4}{|c|}{4.8} \\
\hline & \multicolumn{4}{|c|}{ Total Porosity $\left(\mathrm{m}^{3} \mathrm{~m}^{-3}\right)$} & \multicolumn{4}{|c|}{ Macroporosity $\left(\mathrm{m}^{3} \mathrm{~m}^{-3}\right)$} \\
\hline DS & $0.53 \mathrm{Ba}$ & $0.56 \mathrm{Aa}$ & $0.51 \mathrm{Aa}$ & $0.46 \mathrm{Ab}$ & $0.15 \mathrm{Ba}$ & $0.15 \mathrm{Aa}$ & $0.13 \mathrm{Aa}$ & $0.12 \mathrm{Aa}$ \\
\hline $\mathrm{CT}$ & $0.59 \mathrm{Aa}$ & $0.44 \mathrm{Bb}$ & $0.47 \mathrm{Ab}$ & $0.48 \mathrm{Ab}$ & $0.19 \mathrm{Aa}$ & $0.08 \mathrm{Bb}$ & $0.09 \mathrm{Ab}$ & $0.07 \mathrm{Ab}$ \\
\hline $\mathrm{CV}(\%)$ & \multicolumn{4}{|c|}{6.0} & \multicolumn{4}{|c|}{19.2} \\
\hline
\end{tabular}


Figure 1 - Soil penetration resistance and soil water content under direct seeding (DS) and conventional tillage (CT) for the two crop seasons under study. $*$ Significant at $5 \%$, ns no significant

Soil penetration resistance $(\mathrm{MPa})$

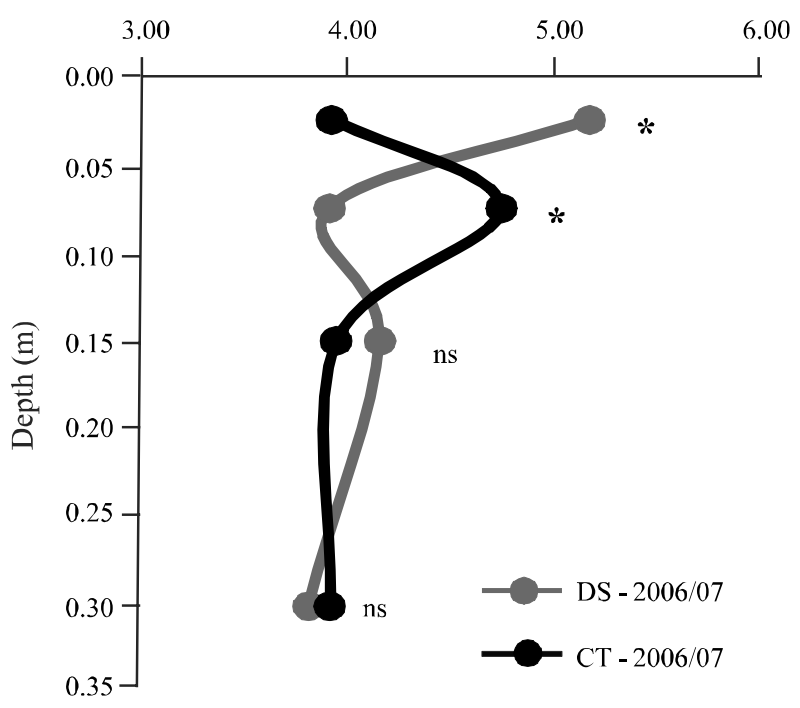

Soil water content $\left(\mathrm{g} \mathrm{g}^{-1}\right)$

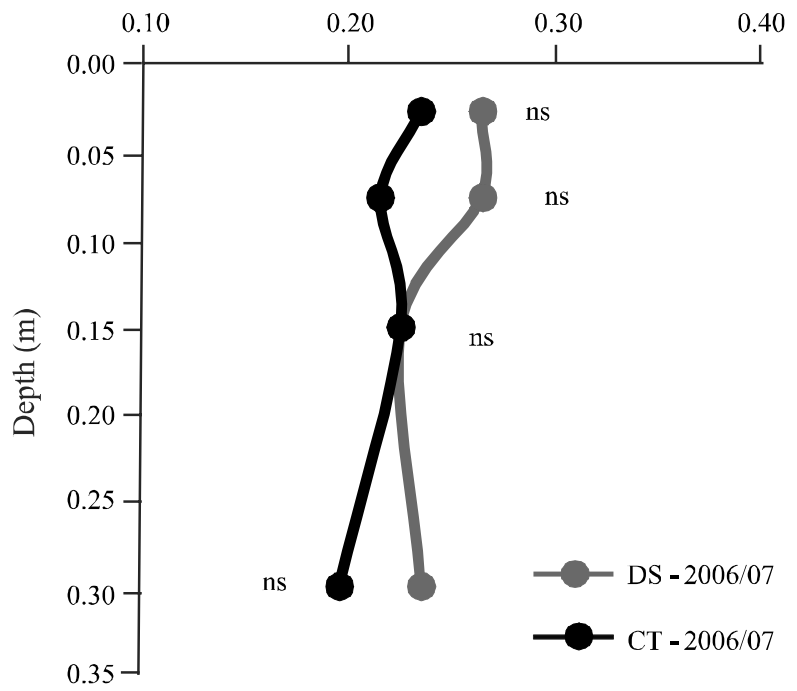

Soil penetration resistance $(\mathrm{MPa})$

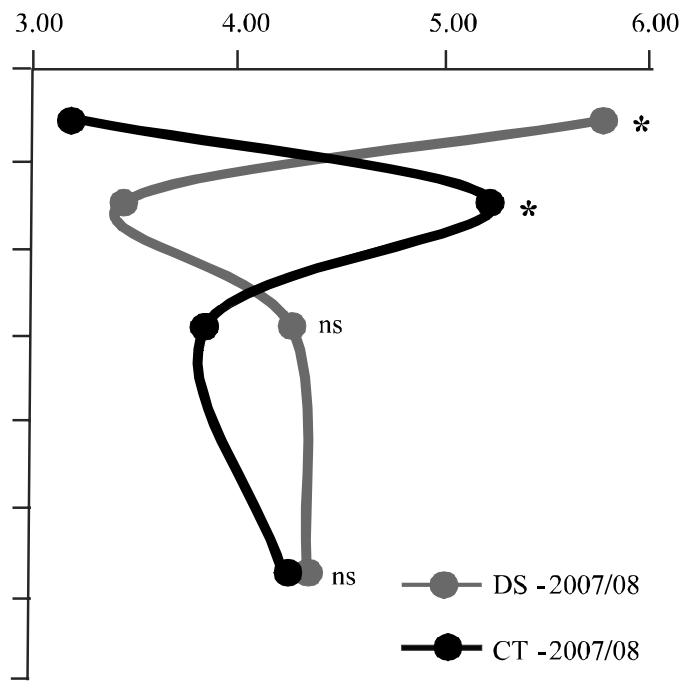

Soil water content $\left(\mathrm{g} \mathrm{g}^{-1}\right)$

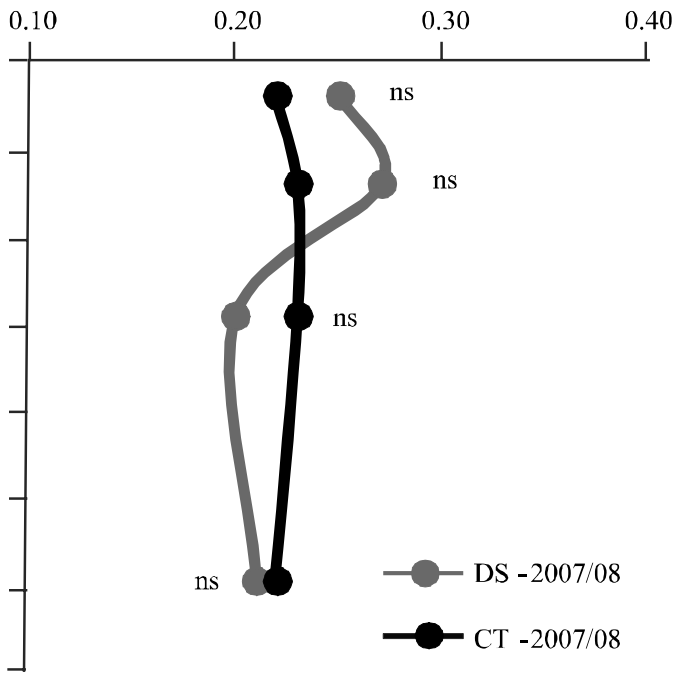

with the passage of time compaction of the soil tends to decrease, due in part to the contribution of organic matter and the activity of microorganisms, mainly in the surface layer, improving the soil structure. This is in agreement with Assis and Lanças (2005).

There were no significant differences between tillage systems for microbial biomass carbon in the soil for the crop seasons 2006/07 and 2007/08, which disagrees with Silva et al. (2007) and Cunha et al. (2011). There was also a decrease in these values at depth under both tillage systems and for the two seasons under study (Table 2). Cunha et al. (2011) also observed a decrease in the value of soil microbial biomass at depth. These results follow the behaviour of soil organic matter. The lack of significance between tillage systems indicated that there was no consolidation of the direct seeding, thereby characterising a process in transition.

Nitrogen levels in the microbial biomass were higher in the soil under direct seeding at depths of 0.00-0.05 and 0.05-0.10 $\mathrm{m}$ for the two seasons under study. Conventional tillage over consecutive years may 
result in fluctuations in the microbial biomass, influenced by fluctuations in soil temperature and the addition of plant residue. Whereas in less disturbed areas, such as under direct seeding, with the accumulation of plant residue on the soil, there is a higher concentration of microbial nitrogen, agreeing with Perez, Ramos and McManus (2005).

The greatest values for microbial biomass nitrogen occurred in the surface layers. This demonstrates that in the surface layers greater input of nitrogen may take place from the root exudates and plant residues which are immobilised by microorganisms in the soil. Microbial biomass is an important component of the nitrogen with potential for mineralisation; the higher the nitrogen content of the microbial biomass therefore, the faster will be its cycling (ANDERSON, 2003). As nitrogen is often one of the most limiting nutrients for agricultural crops, any difference in the rates of mineralisation, immobilization and nitrification may have a significant effect on the sustainability of production systems.

In relation to base respiration, the management systems differed up to a depth of $0.10 \mathrm{~m}$, being greater in soil under conventional tillage for both crop seasons (Table 2). These results corroborate those of Cunha et al. (2011). This is an indication that the

Table 2 - Soil microbiological attributes under direct seeding (DS) and conventional tillage (CT) at four depths and for two crop seasons

\begin{tabular}{|c|c|c|c|c|c|c|c|c|}
\hline \multirow{2}{*}{ Management system* } & \multicolumn{8}{|c|}{ Depth $(\mathrm{m})$} \\
\hline & $0.00-0.05$ & $0.05-0.10$ & $0.10-0.20$ & $0.20-0.40$ & $0.00-0.05$ & $0.05-0.10$ & $0.10-0.20$ & $0.20-0.40$ \\
\hline & \multicolumn{8}{|c|}{ 2006/07 Season } \\
\hline & \multicolumn{4}{|c|}{$\operatorname{MBC}\left(\mu g g^{-1}\right)$} & \multicolumn{4}{|c|}{$\mathrm{MBN}\left(\mu \mathrm{g} \mathrm{g}^{-1}\right)$} \\
\hline DS & $310.6 \mathrm{Aa}$ & $267.7 \mathrm{Aa}$ & $182.8 \mathrm{Ab}$ & $189.1 \mathrm{Ab}$ & $67.2 \mathrm{Aa}$ & $48.9 \mathrm{Ab}$ & $25.5 \mathrm{Ac}$ & $22.7 \mathrm{Ac}$ \\
\hline CT & $275.2 \mathrm{Aa}$ & $223.8 \mathrm{Aa}$ & $160.4 \mathrm{Ab}$ & $135.9 \mathrm{Ab}$ & $53.4 \mathrm{Ba}$ & $34.9 \mathrm{Bb}$ & $25.3 \mathrm{Ab}$ & $15.3 \mathrm{Ac}$ \\
\hline \multirow[t]{2}{*}{$\mathrm{CV}(\%)$} & \multicolumn{4}{|c|}{22.6} & \multicolumn{4}{|c|}{24.0} \\
\hline & \multicolumn{4}{|c|}{$\mathrm{BR}\left(\mu \mathrm{g} \mathrm{g}^{-1} \mathrm{day}^{-1}\right)$} & \multicolumn{4}{|c|}{$\mathrm{qCO}_{2}\left(\mathrm{~g} \mathrm{~g}^{-1} \mathrm{day}^{-1}\right)$} \\
\hline $\mathrm{DS}$ & $54.9 \mathrm{Ba}$ & $42.7 \mathrm{Ba}$ & $29.1 \mathrm{Ab}$ & $24.9 \mathrm{Ab}$ & $0.18 \mathrm{Ba}$ & $0.16 \mathrm{Ba}$ & $0.16 \mathrm{Aa}$ & $0.13 \mathrm{Aa}$ \\
\hline $\mathrm{CT}$ & $70.7 \mathrm{Aa}$ & $64.3 \mathrm{Ab}$ & $30.8 \mathrm{Ac}$ & $24.4 \mathrm{Ac}$ & $0.27 \mathrm{Aa}$ & $0.29 \mathrm{Aa}$ & $0.19 \mathrm{Ab}$ & $0.18 \mathrm{Ab}$ \\
\hline \multirow[t]{2}{*}{$\mathrm{CV}(\%)$} & \multicolumn{4}{|c|}{18.0} & \multicolumn{4}{|c|}{11.7} \\
\hline & \multicolumn{4}{|c|}{ MBC/COT (\%) } & \multicolumn{4}{|c|}{$\mathrm{TN}\left(\mathrm{g} \mathrm{kg}^{-1}\right)$} \\
\hline $\mathrm{DS}$ & $1.6 \mathrm{Ab}$ & $2.2 \mathrm{Aa}$ & $1.5 \mathrm{Ab}$ & $1.4 \mathrm{Ab}$ & $1.86 \mathrm{Aa}$ & $1.79 \mathrm{Aa}$ & $1.57 \mathrm{Ab}$ & $1.26 \mathrm{Ac}$ \\
\hline $\mathrm{CT}$ & 1.1 Aa & $1.1 \mathrm{Ba}$ & $0.8 \mathrm{Aa}$ & $0.8 \mathrm{Aa}$ & $1.63 \mathrm{Aa}$ & $1.61 \mathrm{Aa}$ & $1.53 \mathrm{Aa}$ & $1.21 \mathrm{Ab}$ \\
\hline \multirow[t]{3}{*}{$\mathrm{CV}(\%)$} & \multicolumn{4}{|c|}{17.9} & \multicolumn{4}{|c|}{15.2} \\
\hline & \multicolumn{8}{|c|}{ 2007/08 Season } \\
\hline & \multicolumn{4}{|c|}{$\mathrm{MBC}\left(\mu \mathrm{g} \mathrm{g}^{-1}\right)$} & \multicolumn{4}{|c|}{$\mathrm{MBN}\left(\mu \mathrm{g} \mathrm{g}^{-1}\right)$} \\
\hline DS & 326.3 Aa & $265.7 \mathrm{Ab}$ & $221.4 \mathrm{Ab}$ & $176.1 \mathrm{Ab}$ & $65.3 \mathrm{Aa}$ & $44.0 \mathrm{Ab}$ & $32.9 \mathrm{Ab}$ & $25.3 \mathrm{Ac}$ \\
\hline $\mathrm{CT}$ & $291.9 \mathrm{Aa}$ & $201.5 \mathrm{Ab}$ & $171.9 \mathrm{Ab}$ & $136.5 \mathrm{Ab}$ & $50.5 \mathrm{Ba}$ & $33.0 \mathrm{Bb}$ & $31.8 \mathrm{Ab}$ & $21.9 \mathrm{Ac}$ \\
\hline \multirow[t]{2}{*}{$\mathrm{CV}(\%)$} & \multicolumn{4}{|c|}{25.1} & \multicolumn{4}{|c|}{21.6} \\
\hline & \multicolumn{4}{|c|}{$\mathrm{BR}\left(\mu \mathrm{g} \mathrm{g}^{-1}\right.$ day $\left.^{-1}\right)$} & \multicolumn{4}{|c|}{$\mathrm{qCO} 2\left(\mathrm{~g} \mathrm{~g}^{-1} \mathrm{day}^{-1}\right)$} \\
\hline DS & $50.5 \mathrm{Ba}$ & $36.8 \mathrm{Bb}$ & $32.3 \mathrm{Ab}$ & $28.3 \mathrm{Ab}$ & $0.15 \mathrm{Ba}$ & $0.14 \mathrm{Ba}$ & $0.15 \mathrm{Ba}$ & $0.16 \mathrm{Ba}$ \\
\hline $\mathrm{CT}$ & $66.8 \mathrm{Aa}$ & $53.3 \mathrm{Aa}$ & $39.1 \mathrm{Ab}$ & $31.1 \mathrm{Ab}$ & $0.23 \mathrm{Aa}$ & $0.26 \mathrm{Aa}$ & $0.23 \mathrm{Aa}$ & $0.23 \mathrm{Aa}$ \\
\hline \multirow[t]{2}{*}{$\mathrm{CV}(\%)$} & \multicolumn{4}{|c|}{16.9} & \multicolumn{4}{|c|}{10.7} \\
\hline & \multicolumn{4}{|c|}{$\mathrm{MBC} / \mathrm{COT}(\%)$} & \multicolumn{4}{|c|}{$\mathrm{TN}\left(\mathrm{g} \mathrm{kg}^{-1}\right)$} \\
\hline $\mathrm{DS}$ & $1.8 \mathrm{Ab}$ & $2.5 \mathrm{Aa}$ & $1.6 \mathrm{Ab}$ & $1.3 \mathrm{Ab}$ & $1.79 \mathrm{Aa}$ & $1.63 \mathrm{Ab}$ & $1.54 \mathrm{Ab}$ & $1.22 \mathrm{Ac}$ \\
\hline $\mathrm{CT}$ & 1.2 $\mathrm{Ba}$ & $1.0 \mathrm{Ba}$ & $0.7 \mathrm{Aa}$ & $0.9 \mathrm{Aa}$ & $1.53 \mathrm{Aa}$ & $1.48 \mathrm{Ab}$ & $1.50 \mathrm{Ab}$ & $1.23 \mathrm{Ac}$ \\
\hline $\mathrm{CV}(\%)$ & & 15 & & & & & & \\
\hline
\end{tabular}

MBC: microbial biomass carbon; MBN: microbial biomass nitrogen; BR: base respiration; $\mathrm{qCO}_{2}$ : metabolic quotient; MBC/COT: Microbial quotient; TN: total nitrogen; *Averages followed by the same letter, uppercase in the vertical and lowercase in the horizontal, do not differ by Tukey test at $5 \%$ probability of error. CV: coefficient of variation 
conventional system is producing a greater quantity of $\mathrm{CO}_{2}$ resulting from metabolic activity, promoting greater mineralisation of organic compounds in the soil (MOURA; LACERDA; RAMOS, 2013). High values for base respiration do not always indicate desirable conditions, as a high rate of respiration can in the short term mean the release of nutrients to plants, and in the long term, the loss of soil organic carbon to the atmosphere and soil degradation, making agricultural activity unsustainable (CUNHA et al., 2011).

A similar trend was observed for the metabolic quotient, with higher values in soil under conventional tillage at depths of $0.00-0.05 \mathrm{~m}$ and $0.05-0.10 \mathrm{~m}$ for the 2006/07 season, and at all depths for 2007/08. These results are in agreement with Silva et al. (2007) and Cunha et al. (2011). High values for the metabolic quotient demonstrate the imbalance of agricultural areas (MOURA; LACERDA; RAMOS, 2013), as in the case of plots subjected to conventional tillage. This type of management promotes disruption of the soil aggregates, increasing the mineralisation of the organic matter content and increasing the release of carbon dioxide into the atmosphere (CARNEIRO et al., 2009). Similar results were found by Franchini et al. (2007), who, in long-term trials in Paraná, observed the lower metabolic rate in soil under direct seeding contribute to a greater accumulation of carbon in the soil.
No significant differences in total nitrogen were seen between management systems at the depths and for the seasons under study (Table 2). However, under the direct seeding in the 2006/07 season, the distribution of total nitrogen in the soil profile indicated a greater concentration on the surface, in agreement with Perez, Ramos and McManus (2005). It was expected that under the direct seeding, with soil being turned only in the planting furrow, there would be a significant increase in the total nitrogen of the soil compared to conventional tillage, as reported by Perez, Ramos and McManus (2005). According to Ros et al. (2003) the decomposition rate of plant residue is associated with the carbon to nitrogen ratio $(\mathrm{C} / \mathrm{N})$ of the tissue, for this reason nongrass species have a higher rate of decomposition when compared to grasses such as oats. One reflection of this is the intensity of the phenomenon of nitrogen immobilisation, which is the main cause of less $\mathrm{N}$ being available to plants under a direct seeding in relation to a system which involves turning of the soil.

The initial plant density did not differ significantly between the management systems for the $2006 / 07$ or $2007 / 08$ seasons (Table 3 ). This shows that from the point of view of crop establishment, there is no need for preparation practices that cause soil compaction, disruption of aggregates or greater exposure to erosive factors. Similar results were observed by Santos et al.

Table 3 - Biometric parameters of bean crops under direct seeding (DS) and conventional tillage (CT)

\begin{tabular}{|c|c|c|c|}
\hline \multirow{2}{*}{ Biometric parameter* } & \multicolumn{3}{|c|}{ Management system } \\
\hline & $\mathrm{CT}$ & DS & $\mathrm{CV}(\%)$ \\
\hline \multicolumn{4}{|c|}{ 2006/07 Season } \\
\hline Initial plant density (plants $\mathrm{m}^{-2}$ ) & $28.3 \mathrm{a}$ & $31.7 \mathrm{a}$ & 11.6 \\
\hline Number of pods per plant & $7.2 \mathrm{~b}$ & $13.2 \mathrm{a}$ & 20.9 \\
\hline Number of grains per pod & $4.8 \mathrm{a}$ & $4.9 \mathrm{a}$ & 10.7 \\
\hline Thousand-grain weight (g) & $165.1 \mathrm{~b}$ & $225.1 \mathrm{a}$ & 9.9 \\
\hline Total shoot weight (g) & $21.0 \mathrm{a}$ & $23.0 \mathrm{a}$ & 17.7 \\
\hline Harvest index $(\%)$ & $54.4 \mathrm{~b}$ & $67.2 \mathrm{a}$ & 13.7 \\
\hline \multicolumn{4}{|c|}{ 2007/08 Season } \\
\hline Initial plant density (plants $\mathrm{m}^{-2}$ ) & $22.5 \mathrm{a}$ & $27.0 \mathrm{a}$ & 10.4 \\
\hline Number of pods per plant & $5.4 \mathrm{~b}$ & $14.3 \mathrm{a}$ & 18.7 \\
\hline Number of grains per pod & $4.5 \mathrm{a}$ & $4.9 \mathrm{a}$ & 10.2 \\
\hline Thousand-grain weight (g) & $145.1 \mathrm{~b}$ & $205.1 \mathrm{a}$ & 16.5 \\
\hline Total shoot weight (g) & $23.0 \mathrm{a}$ & $20.0 \mathrm{a}$ & 17.5 \\
\hline Harvest index (\%) & $50.1 \mathrm{~b}$ & $70.2 \mathrm{a}$ & 14.8 \\
\hline
\end{tabular}

*Averages followed by the same letter, uppercase in the vertical and lowercase in the horizontal, do not differ by Tukey test at $5 \%$ probability of error. $\mathrm{CV}$ : coefficient of variation 
(2004), when studying the development of bean crops under different management systems.

There was a significant difference between the management systems in 2006/07 and 2007/08 in relation to the number of pods per plant (Table 3 ). The direct seeding resulted in an increase of over $83 \%$ for this parameter compared to conventional tillage. The thousand-grain weight and harvest index of the bean plants were higher under direct seeding compared to conventional tillage for both seasons, which is in accordance with Santos et al. (2004). The attributes, number of grains per pod and total shoot weight did not differ between management systems for the two seasons under study, agreeing with Arf et al. (2004).

\section{CONCLUSIONS}

1. The direct seeding displayed better physical quality of the subsoil and increased soil compaction of the surface layer, however this did not adversely affect the biometric parameters of the bean plants;

2. The management system with direct seeding showed better soil biological quality, having a positive influence on the biometric parameters of the bean crop.

\section{REFERENCES}

AMARAL, H. F. et al. Alterações nas propriedades químicas e microbianas de solos cultivados com videiras sob manejo orgânico e convencional no sul do Brasil. Revista Brasileira de Ciência do Solo, v. 35, n. 5, p. 1517-1526, 2011.

ANDERSON, T. H. Microbial eco-physiological indicators to asses soil quality. Agriculture, Ecosystems \& Environment, v. 98 , n. 1/3, p. 285-293, 2003.

ARF, O. et al. Manejo do solo, água e nitrogênio no cultivo de feijão. Pesquisa Agropecuária Brasileira, v. 39, n. 2, p. 131138, 2004.

ASSIS, R. L.; LANÇAS, K. P. Avaliação dos atributos físicos de um Nitossolo Vermelho distroférrico sob sistema plantio direto, preparo convencional e mata nativa. Revista Brasileira de Ciência do Solo, v. 29, n. 4, p. 515-522, 2005.

BERTOL, I. et al. A. Propriedades físicas do solo sob preparo convencional e semeadura direta em rotação e sucessão de culturas, comparadas às do campo nativo. Revista Brasileira de Ciência do Solo, v. 28, n. 1, p. 155-163, 2004.

CARNEIRO, M. A. C. et al. Atributos físicos, químicos e biológicos de solo de cerrado sob diferentes sistemas de uso e manejo. Revista Brasileira de Ciência do Solo, v. 33, n. 1, p. 147-157, 2009.

CUNHA, E. Q. et al. Sistemas de preparo do solo e culturas de cobertura na produção orgânica de feijão e milho: II- Atributos biológicos do solo. Revista Brasileira de Ciência do Solo, v. 35, n. 2, p. 603-611, 2011.

EMPRESABRASILEIRADEPESQUISAAGROPECUÁRIA. Sistema Brasileiro de Classificação de Solos. 3. ed. Brasília: Embrapa, 2013. 353 p.

EMPRESA BRASILEIRA DE PESQUISA AGRPECUÁRIA. Manual de métodos de análise de solos. 2. ed. rev. Rio de Janeiro: Embrapa Solos, 2011. 230 p.

FRANCHINI, J. C. et al. Microbiological parameters as indicators of soil quality under various soil management and crop rotation systems in southern Brazil. Soil and Tillage Research, v. 92, n. 1/2, p. 18-29, 2007.

JENKINSON, D. S. Determination of microbial biomass carbon and nitrogen in soils. In: WILSON, J. R. Advances in Nitrogen Cycling Agricultural Systems. Wallingford: CAB international, 1988. p. 368-386.

KAISER, D. R. et al. Intervalo hídrico ótimo no perfil explorado pelas raízes de feijoeiro em um Latossolo sob diferentes níveis de compactação. Revista Brasileira de Ciência do Solo, v. 33, n. 4, p. 845-855, 2009.

KÖPPEN, W. Climatología: con un estudio de los climas de la tierra. México: Fondo de Cultura Económica, 1948. 478 p.

MOURA, L. N. A.; LACERDA, M. P. C.; RAMOS, M. L. G. Qualidade de Organossolo sob diferentes usos antrópicos em áreas de preservação permanente no Distrito Federal. Revista Brasileira de Engenharia Agrícola e Ambiental, v. 17, n. 1, p. 33-39, 2013.

PEREZ, K. S. S.; RAMOS, M. L. G.; McMANUS, C. Nitrogênio da biomassa microbiana em solo cultivado com soja, sob diferentes sistemas de manejo, nos Cerrados. Pesquisa Agropecuária Brasileira, v. 40, n. 2, p. 137-144, 2005.

PRAMER,D.; SCHMIDT,E.L. Experimental Soil Microbiology. Minneapolis: Burgess Publishing Company, 1964. 107 p.

ROS, C. O. et al. Disponibilidade de nitrogênio e produtividade de milho e trigo com diferentes métodos de adubação nitrogenada no sistema plantio direto. Ciência Rural, v. 33, n. 5, p. 799-804, 2003.

SANTOS, R. L. L. et al. Comportamento de cultivares de feijoeirocomum em sistema convencional e plantio direto com diferentes palhadas. Ciência e Agrotecnologia, v. 28, n. 5, p. 978-989, 2004.

SECCO, D. et al. Atributos físicos e produtividade de culturas em um Latossolo Vermelho argiloso sob diferentes sistemas de manejo. Revista Brasileira de Ciência do Solo, v. 29, n. 3, p. 407-414, 2005

SILVA, M. B. et al. Atributos biológicos do solo sob influência da cobertura vegetal e do sistema de manejo. Pesquisa Agropecuária Brasileira, v. 42, n. 12, p. 1755-1761, 2007.

STOLF, R.; REICHARDT, K.; VAZ, C. P. M. Response to "Comments on 'Simultaneous Measurement of Soil Penetration Resistance and Water Content with a Combined PenetrometerTDR Moisture Probe' and 'A Dynamic Cone Penetrometer for Measuring Soil Penetration Resistance'”. Soil Science Society American Journal, v. 69, n. 3, p. 927-929, 2005. 
TORMENA, C. A. et al. Quantification of the soil physical quality of a tropical Oxisol using the $\mathrm{s}$ index. Scientia Agricola, v. 65, n. 1, p. 56-60, 2008.

TORMENA, C. A; SILVA, A. P.; LIBARDI, P. L. Caracterização do intervalo hídrico ótimo de um Latossolo Roxo sob plantio direto. Revista Brasileira de Ciência do Solo, v. 22, n. 4, p. 573-581, 1998.
VANCE, E. D.; BROOKES, P. C.; JENKINSON, D. S. An extraction method for measuring soil microbial biomass C. Soil Biology and Biochemistry, v. 19, n. 6, p. 703-707, 1987.

WENDLING, B. et al. Carbono orgânico e estabilidade de agregados de um Latossolo Vermelho sob diferentes manejos. Pesquisa Agropecuária Brasileira, v. 40, n. 5, p. 487-494, 2005. 